\title{
Application of Chemical and Biofertilizers on Growth and Biomass Production of Madhuca latifolia (Mahua) Seedlings
}

\author{
Archana Sharma \\ Scientist 'D' MP State Forest Research Institute, Jabalpur (MP) 482008, India \\ archanasfri@gmail.com
}

\begin{abstract}
The doses of inorganic fertilizers and biofertilizers (VA- mycorrhzas, phosphorus solubilizing bacteria and Azotobactor) for Madhuca latifolia (Mahua) have not been standardized, so far. Therefore, this experiment was undertaken to compare the effects of inorganic fertilizers and biofertilizers on the growth and biomass production in Mahua seedlings. The study was conducted in green house of the institute. Twelve months old seedlings of Madhuca latifolia were selected for study. Total 24 treatments were tried using biofertilizers, and chemical fertilizers, the result indicates that biofertilizers were found much superior to chemical fertilizers in improving the soil fertility. Azotobactor was found the most efficient in improving the organic matter and nitrogen whereas PSB application is the best for improving phosphorus and potash. PSB has mobilized unavailable " $P$ " to available form to the plants, which has resulted in increasing the growth of seedlings.
\end{abstract}

Keywords: Biofertilizers, Seedling growth, Biomass

\section{Introduction}

Biofertilizers refer to micro - organisms consisting of bacteria, fungi, algae etc., which fix the atmospheric nitrogen and enhance the solubility and availability of soil nutrients. These individually, or in combination, are known for increasing plant growth by way of inducing various biochemical activities in the soil. Their significance lies in their ability to supplement and immobilize soil nutrients with minimum use of nonrenewable resources.

Biofertilizers develop symbiotic association with plants that supply protected niche to the microbes for growth and in return, the plants receive continuous supply of reduced nitrogen. Biofertilizers help in the growth of plants and in increasing productivity by nitrogen fixation, phosphorus utilization, preventing attack of root pathogen and enhancement of tolerance to moisture stress condition in the plants in the most natural way. There are mainly two groups of biofertilizers i.e., symbiotic and non symbiotic. The symbiotic group comprises of Rhizobium, Frankia (Nitrogen fixing organism) and Mycorrhizae (especially for phosphorus) and covers most of the terrestrial and aquatic plant community, while non-symbiotic group includes Azotobactor, Azospirllum, Pseudomonas, etc., living in the environment. The role of micro-organisms is very specific and plants interact with this micro - organisms to fulfill their requirements for various minerals. The function and potentialities of various beneficial micro--organisms have been documented by different scientific experiments 
(Bagyaraj et. al., 1996, Chandra et. al., 1999). The application of biofertilizers in agriculture sector is well recognized worldwide through comprehensive studies on agriculture crops (Harley and Smith, 1983; Powell and Bagyraj, 1984; Sieverding and Toro, 1998; Subha Rao, 1984; and Raj et. al., 1981) but very little information on their effects on forestry species is available in literature.

Moreover, the doses of inorganic fertilizers and biofertilizers (VA- mycorrhizae phosphorus solubilizing bacteria and azotobactor) for Madhuca latifolia (Mahua) var. latifolia have not been standardized, so far. The present paper deals undertaken to compare the effects of inorganic fertilizers and biofertilizers on the growth and biomass production in Mahua seedlings.

\section{Methodology}

The study was conducted in green house. Twelve months old seedlings of Madhuca latifolia were selected for study and the potting mixture comprised of soil, sand and FYM in 1: 1: 2 ratios. The mixture was analyzed for its physico - chemical properties prior to experimental use. Total 24 treatments were tried using biofertilizers, and chemical fertilizers. Details are as under:

\section{Treatments with Various Chemicals and Biofertilizers Control - T0 (Untreated)}

\begin{tabular}{|c|c|c|}
\hline \multicolumn{3}{|c|}{ Biofertilizers } \\
\hline Treatments & VAM Micorrhizae & Doses \\
\hline 1 & $\mathrm{VT}_{1}$ & $20 \mathrm{gm} /$ seedling \\
\hline 2 & $\mathrm{VT}_{2}$ & $40 \mathrm{gm} /$ seedling \\
\hline 3 & $\mathrm{VT}_{3}$ & $60 \mathrm{gm} /$ seedling \\
\hline 4 & $\mathrm{VT}_{4}$ & $80 \mathrm{gm} /$ seedling \\
\hline & PSB (phosphorus solubilizing bacteria) & \\
\hline 5 & $\mathrm{PT}_{1}$ & $20 \mathrm{gm} /$ seedling \\
\hline 6 & $\mathrm{PT}_{2}$ & $40 \mathrm{gm} /$ seedling \\
\hline 7 & $\mathrm{PT}_{3}$ & $60 \mathrm{gm} /$ seedling \\
\hline 8 & $\mathrm{PT}_{4}$ & $80 \mathrm{gm} /$ seedling \\
\hline & Azotobactor & \\
\hline 9 & $\mathrm{AT}_{1}$ & $20 \mathrm{gm} /$ seedling \\
\hline 10 & $\mathrm{AT}_{2}$ & $40 \mathrm{gm} /$ seedling \\
\hline 11 & $\mathrm{AT}_{3}$ & $60 \mathrm{gm} /$ seedling \\
\hline 12 & $\mathrm{AT}_{4}$ & $80 \mathrm{gm} /$ seedling \\
\hline & Chemical Fertilizers-- & \\
\hline & Urea & \\
\hline 13 & $\mathrm{UT}_{1}$ & $2 \mathrm{gm} /$ seedling \\
\hline 14 & $\mathrm{UT}_{2}$ & $4 \mathrm{gm} /$ seedling \\
\hline 15 & $\mathrm{UT}_{3}$ & $6 \mathrm{gm} / \mathrm{seedling}$ \\
\hline 16 & $\mathrm{UT}_{4}$ & $8 \mathrm{gm} /$ seedling \\
\hline & SSP (Single super phosphate) & \\
\hline 17 & $\mathrm{ST}_{1}$ & $2 \mathrm{gm} /$ seedling \\
\hline 18 & $\mathrm{ST}_{2}$ & $4 \mathrm{gm} /$ seedling \\
\hline 19 & $\mathrm{ST}_{3}$ & $6 \mathrm{gm} /$ seedling \\
\hline 20 & $\mathrm{ST}_{4}$ & $8 \mathrm{gm} /$ seedling \\
\hline & Murate of potash & \\
\hline 21 & $\mathrm{M} \mathrm{T}_{1}$ & $2 \mathrm{gm} / \mathrm{seedling}$ \\
\hline 22 & $\mathrm{M} \mathrm{T}_{2}$ & $4 \mathrm{gm} /$ seedling \\
\hline 23 & $\mathrm{M} \mathrm{T}_{3}$ & $6 \mathrm{gm} /$ seedling \\
\hline 24 & $\mathrm{M} \mathrm{T}_{4}$ & $8 \mathrm{gm} /$ seedling \\
\hline
\end{tabular}




\section{Experimental Design}

Experimental design was RBD (Random block design). Three replicates each of 15 seedlings were taken for each treatment. Total 390 seedlings were taken for this study

\section{Inoculation of Biofertilizers}

Different doses of biofertilizers were inoculated just after transplantation into polypots. Two to three holes up to15 $\mathrm{cm}$ depth were made in the soil adjacent to seedlings for inoculation of biofertilizers. Biofertilizers viz ; VAM, PSB and Azotobactor were inoculated and holes were refilled with the surrounding soil. Normal watering was done after inoculation. Similar techniques were followed for application of inorganic fertilizers but holes were made slightly away from the seedlings to avoid direct contact with the seedlings.

Observations were recorded on the following parameters:

- Soil nutrients status

- Survival percentage of seedlings.

- Seedling growth in terms of root and shoot length

- Collar diameter.

- Survival percentage and growth of seedlings were recorded at there months interval up to 24 months.

- Seedling biomass in terms of root and shoot biomass

\section{Soil Nutrients Analysis}

$\mathrm{pH}$ of the potting mixture was estimated by $\mathrm{pH}$ meter. Organic matter content in soil mixture was estimated by method prescribed by Wakley and Blake (1934). Nitrogen estimation was done through Kjeltec 2300, while estimation of available phosphorus in soil was made by extraction with $\mathrm{NaHCO}_{3}$ (Olsen et al, 1954) and potassium with flame photometer.

\section{Measurement of Growth and Biomass of Seedling}

Nine plants from each treatment (three from each replicate) were taken for measuring growth performance. The height and girth of seedlings were measured by a tape and vernier callipers, respectively. The dry biomass was estimated after keeping plant material in oven at $70^{\circ} \mathrm{C}$ for 3 days.

Table 1. Soil Analysis Before and After Experiments (Mahua)

\begin{tabular}{|c|c|c|c|c|c|c|}
\hline \multirow{2}{*}{$\begin{array}{l}\text { S. } \\
\text { No. }\end{array}$} & \multirow[t]{2}{*}{ Treatments } & \multicolumn{5}{|c|}{ Parameters } \\
\hline & & $\mathrm{pH}$ & OM\% & $\mathbf{N} \%$ & $\mathbf{P}(\mathrm{ppm})$ & $\mathrm{J}$ (ppm) \\
\hline A & $\begin{array}{l}\text { Analysis of potting mixture before } \\
\text { experiments }\end{array}$ & 7.23 & 2.21 & 0.014 & 3.73 & 3.56 \\
\hline$B$ & \multicolumn{6}{|c|}{ Analysis of potting mixture after experiments } \\
\hline 1 & Control & 6.86 & 0.78 & 0.03 & 5.14 & 64.20 \\
\hline 2 & VAM - & 7.46 & 2.29 & 1.10 & 7.40 & 119.98 \\
\hline 3 & $\mathrm{~T}_{2}$ & 7.35 & 2.24 & 0.98 & 6.17 & 137.22 \\
\hline 4 & $\mathrm{~T}_{3}$ & 7.40 & 2.30 & 1.22 & 7.39 & 140.19 \\
\hline 5 & $\mathrm{~T}_{4}$ & 7.43 & 2.16 & 1.32 & 7.42 & 136.64 \\
\hline
\end{tabular}




\begin{tabular}{|c|c|c|c|c|c|c|}
\hline \multirow{2}{*}{$\begin{array}{l}\text { S. } \\
\text { No. }\end{array}$} & \multirow[t]{2}{*}{ Treatments } & \multicolumn{5}{|c|}{ Parameters } \\
\hline & & $\mathrm{pH}$ & OM\% & $\mathbf{N} \%$ & $\mathbf{P}$ (ppm) & $\mathrm{J}$ (ppm) \\
\hline 6 & PSB & 7.09 & 2.09 & 1.31 & 8.49 & 182.44 \\
\hline 7 & $T_{2}$ & 7.17 & 2.12 & 1.55 & 10.82 & 190.44 \\
\hline 8 & $T_{3}$ & 7.20 & 2.19 & 1.47 & 11.75 & 200.41 \\
\hline 9 & $\mathrm{~T}_{4}$ & 7.12 & 2.15 & 1.54 & 11.72 & 199.09 \\
\hline 10 & AZOTO- & 7.18 & 2.12 & 1.37 & 8.33 & 171.91 \\
\hline 11 & $\mathrm{~T}_{2}$ & 7.24 & 2.10 & 2.14 & 8.50 & 176.34 \\
\hline 12 & $\mathrm{~T}_{3}$ & 7.18 & 2.23 & 2.13 & 9.70 & 185.09 \\
\hline 13 & $T_{4}$ & 7.17 & 2.39 & 2.17 & 9.59 & 189.14 \\
\hline 14 & NPK - Control & 6.70 & 0.86 & 0.033 & 5.37 & 77.13 \\
\hline 15 & $\begin{array}{lll}\text { Urea } & - & T_{1}\end{array}$ & 6.33 & 0.88 & 0.044 & 3.70 & 68.56 \\
\hline 16 & $\mathrm{~T}_{2}$ & 6.30 & 0.80 & 0.042 & 3.80 & 68.27 \\
\hline 17 & $\mathrm{~T}_{3}$ & 6.27 & 0.89 & 0.039 & 3.55 & 69.30 \\
\hline 18 & $\mathrm{~T}_{4}$ & 6.34 & 0.76 & 0.040 & 3.66 & 70.04 \\
\hline 19 & SSP & 6.17 & 1.14 & 0.057 & 4.69 & 81.42 \\
\hline 20 & $\mathrm{~T}_{2}$ & 6.17 & 0.98 & 0.055 & 4.53 & 81.30 \\
\hline 21 & $\mathrm{~T}_{3}$ & 6.29 & 1.07 & 0.054 & 3.83 & 80.56 \\
\hline 22 & $T_{4}$ & 6.15 & 1.03 & 0.057 & 3.54 & 82.36 \\
\hline 23 & Murate of potash - & 6.27 & 1.10 & 0.055 & 4.49 & 68.74 \\
\hline 24 & $\mathrm{~T}_{2}$ & 6.20 & 1.19 & 0.048 & 4.33 & 70.68 \\
\hline 25 & $T_{3}$ & 6.22 & 1.07 & 0.059 & 3.94 & 68.92 \\
\hline 26 & $T_{4}$ & 6.34 & 1.09 & 0.058 & 4.83 & 66.39 \\
\hline
\end{tabular}

Table 2. Root / Shoot Length and Biomass Observation of Mahua Seedlings

\begin{tabular}{|c|c|c|c|c|c|c|c|c|c|c|}
\hline \multirow{2}{*}{$\begin{array}{c}\text { S } \\
\text { No. }\end{array}$} & \multirow[t]{2}{*}{ Treatments } & \multirow{2}{*}{$\begin{array}{l}\text { Root } \\
\text { length } \\
\text { (cm) }\end{array}$} & \multirow{2}{*}{$\begin{array}{l}\text { Shoot } \\
\text { length } \\
\text { (cm) }\end{array}$} & \multirow{2}{*}{$\begin{array}{c}\text { Total } \\
\text { length of } \\
\text { seedling }\end{array}$} & \multirow{2}{*}{$\begin{array}{c}\text { Collar } \\
\text { Diameter } \\
(\mathbf{c m})\end{array}$} & \multirow{2}{*}{$\begin{array}{l}\text { Survi } \\
\text { val } \\
(\%)\end{array}$} & \multicolumn{2}{|c|}{ Wet biomass } & \multicolumn{2}{|c|}{ Dry biomass } \\
\hline & & & & & & & $\begin{array}{l}\text { Root } \\
\text { (gm) }\end{array}$ & $\begin{array}{c}\text { Shoot } \\
\text { (gm) }\end{array}$ & $\begin{array}{l}\text { Root } \\
\text { (gm) }\end{array}$ & $\begin{array}{c}\text { Shoot } \\
\text { (gm) }\end{array}$ \\
\hline 1 & Control (To) & 17.59 & 22.2 & 39.79 & 0.61 & 80 & 15.13 & 6.31 & 7.59 & 2.69 \\
\hline \multicolumn{11}{|c|}{ Biofertilizers } \\
\hline 2 & VAM (VT1) & 22.66 & 30.66 & 53.32 & 0.70 & 90 & 29.5 & 9.06 & 11.69 & 3.72 \\
\hline 3 & VAM (VT2) & 25.45 & 25.70 & 51.15 & 0.73 & 90 & 20.75 & 10.51 & 9.84 & 4.50 \\
\hline 4 & VAM (I & 31.85 & 25.75 & 56.19 & 0.71 & 90 & 23.41 & 13.43 & 10.89 & 6.47 \\
\hline 5 & VAM ( & 21.13 & 27.70 & 48.83 & 0.72 & 90 & 27.23 & 13.26 & 12.99 & 6.33 \\
\hline 6 & PSB (PT1) & 21.63 & 26.16 & 47.79 & 0.82 & 80 & 37.20 & 17.71 & 16.27 & 8.28 \\
\hline 7 & PSB (PT2) & 27.75 & 28.44 & 56.19 & 0.83 & 80 & 36.81 & 18.11 & 17.87 & 8.96 \\
\hline 8 & PSB (PT1) & 40.16 & 29.49 & 69.65 & 0.93 & 100 & 40.35 & 18.20 & 18.00 & 12.40 \\
\hline 9 & PSB (PT1) & 31.05 & 30.43 & 61.48 & 0.83 & 90 & 37.60 & 25.66 & 18.35 & 8.52 \\
\hline 10 & Azoto. (AT1) & 30.8 & 27.81 & 58.61 & 0.75 & 80 & 37.50 & 20.66 & 13.82 & 7.29 \\
\hline 11 & Azoto. (AT1) & 39.26 & 25.22 & 64.48 & 0.82 & 90 & 38.55 & 29.83 & 15.17 & 10.59 \\
\hline 12 & Azoto. (AT1) & 36.83 & 27.42 & 66.25 & 0.88 & 100 & 40.18 & 20.20 & 19.55 & 10.95 \\
\hline 13 & Azoto. (AT1) & 38.83 & 26.82 & 65.65 & 0.86 & 100 & 39.18 & 27.98 & 10.85 & 7.97 \\
\hline \multicolumn{11}{|c|}{ Chemical fertilizers } \\
\hline 14 & Urea (UT1) & 30.90 & 27.25 & 58.15 & 0.76 & 86.7 & 13.16 & 7.45 & 4.59 & 2.62 \\
\hline 15 & Urea (UT2) & 24.91 & 24.30 & 49.21 & 0.67 & 84.9 & 22.83 & 9.08 & 6.89 & 3.49 \\
\hline 16 & Urea (UT3) & 23.33 & 25.79 & 49.12 & 0.68 & 82.8 & 9.78 & 8.73 & 4.07 & 3.13 \\
\hline 17 & Urea (UT4) & 23.25 & 28.29 & 48.54 & 0.68 & 77.8 & 21.23 & 9.85 & 5.33 & 2.49 \\
\hline 18 & SSP (T1) & 24.88 & 21.14 & 46.02 & 0.70 & 77.8 & 13.71 & 7.60 & 3.65 & 2.19 \\
\hline 19 & SSP. (T2) & 27.03 & 23.71 & 50.74 & 0.72 & 77.8 & 27.65 & 11.46 & 4.84 & 2.29 \\
\hline 20 & SSP. (T3) & 25.60 & 22.33 & 47.93 & 0.73 & 100 & 24.9 & 13.40 & 4.25 & 2.39 \\
\hline 21 & SSP. (T4) & 35.46 & 20.03 & 55.49 & 0.72 & 66.7 & 14.00 & 8.28 & 6.94 & 3.75 \\
\hline
\end{tabular}




\begin{tabular}{|c|c|c|c|c|c|c|c|c|c|c|}
\hline \multirow{2}{*}{$\begin{array}{c}\text { S } \\
\text { No. }\end{array}$} & \multirow[t]{2}{*}{ Treatments } & \multirow{2}{*}{$\begin{array}{l}\text { Root } \\
\text { length } \\
\text { (cm) }\end{array}$} & \multirow{2}{*}{$\begin{array}{l}\text { Shoot } \\
\text { length } \\
\text { (cm) }\end{array}$} & \multirow{2}{*}{$\begin{array}{c}\text { Total } \\
\text { length of } \\
\text { seedling }\end{array}$} & \multirow{2}{*}{$\begin{array}{c}\text { Collar } \\
\text { Diameter } \\
(\mathbf{c m})\end{array}$} & \multirow{2}{*}{$\begin{array}{c}\text { Survi } \\
\text { val } \\
(\%)\end{array}$} & \multicolumn{2}{|c|}{ Wet biomass } & \multicolumn{2}{|c|}{ Dry biomass } \\
\hline & & & & & & & $\begin{array}{l}\text { Root } \\
\text { (gm) }\end{array}$ & $\begin{array}{c}\text { Shoot } \\
(\mathrm{gm})\end{array}$ & $\begin{array}{l}\text { Root } \\
(\mathrm{gm})\end{array}$ & $\begin{array}{c}\text { Shoot } \\
\text { (gm) }\end{array}$ \\
\hline 22 & $\begin{array}{l}\text { Murate of } \\
\text { potash (T1) }\end{array}$ & 26.48 & 23.67 & 50.15 & 0.70 & 100 & 17.53 & 8.96 & 4.51 & 2.64 \\
\hline 23 & $\begin{array}{l}\text { Murate of } \\
\text { potash (T2) }\end{array}$ & 29.48 & 19.00 & 48.48 & .069 & 88.9 & 12.51 & 7.33 & 3.07 & 1.99 \\
\hline 24 & $\begin{array}{l}\text { Murate of } \\
\text { potash (T3) }\end{array}$ & 29.33 & 20.40 & 49.73 & 0.67 & 55.6 & 16.83 & 7.73 & 3.49 & 1.94 \\
\hline 25 & $\begin{array}{l}\text { Murate of } \\
\text { potash (T4) }\end{array}$ & 20.31 & 18.61 & 38.92 & 0.68 & 77.8 & 16.20 & 7.93 & 2.74 & 2.08 \\
\hline
\end{tabular}

Table 3. Statistical Analysis for ANOVA

\begin{tabular}{|l|c|c|c|c|c|}
\hline & Sum of Squares & df & Mean Square & F & Sig. \\
\hline Between Groups & 4410.908 & 24 & 183.788 & 423.513 & .000 \\
\hline Within Groups & 21.698 & 50 & .434 & & \\
\hline Total & 4432.606 & 74 & & & \\
\hline
\end{tabular}

\section{Results}

\subsection{Effect of Chemical Fertilizers and Biofertilizers on Soil Properties}

Table 1 gives the comparative values of different soil parameters; Effect of the application of fertilizers on each is discussed below-

(1) pH: Application of chemical fertilizers resulted into lowering of $\mathrm{pH}$ (increasing the acidity). It varied from 6.15 in case of ST4 ( 8 gm of SSP / seedling) to 6.34 in case of UT4 (8 $\mathrm{gm}$ of urea / seedling) and MT4 (8 gm of murate of potash / seedling), whereas the $\mathrm{pH}$ value in control was 6.70. On the contrary, application of the bio-fertilizers had opposite effect. It increased the $\mathrm{pH}$ from 6.86 (control) to as much as 7.46 in case of VT1 (20 gm. / seedling). Thus, it can be concluded that application of biofertilizers could be beneficial for improving acidic soils, whereas chemical fertilizers may improve basic soils.

(2) Organic matter: Significant improvement was noticed in organic matter content after application of biofertilizers, as is evident from the perusal of Table 1 . Whereas, the value of OM (Organic matter) percentage was only 0.78 in control, it increased up to 2.39 with AT4 (80 gm Azotobactor / seedling). In other treatments also, the values ranged between 2.09 with PT1 (20 gm PSB / seedling) and 2.29 with VT1 (20 gm VAM / seedling). On the other hand, the effect of application of chemical fertilizers is only marginal, the maximum value reaching only up to 1.19 in case of MT2 (4 gm of murate of potash / seedling).

(3) N, P, K: Similar observations were recorded for nitrogen, phosphorus and potassium also. There was significant improvement in N,P and $\mathrm{K}$ after application of biofertilizers. The value of $\mathrm{N}$ was only $0.014 \%$ in potting mixture before the experiment and it increased up to $2.17 \%$ in case of AT4 (80 gm Azotobactor / seedling). Other treatments also resulted in significant improvement varying from $0.98 \%$ (VT2) to $1.10 \%$ (VT1). The application of Azotobactor caused the maximum improvement, the values ranging from $1.37 \%$ (AT1) to $2.17 \%$ (AT4). On the other hand, the application of chemical fertilizers showed only marginal improvement in nitrogen content, the maximum value being only $0.059 \%$ with MT3 (6 gm of murate of potash / seedling) and the minimum being only 0.039 with UT3 (6 gm urea / seedling). 
Similarly, the phosphorus content also increases significantly after application of biofertilizers. Before experiment, it was $3.73 \mathrm{ppm}$ in the potting mixture. It has increased up to $11.75 \mathrm{ppm}$ with PT3 (60 gm PSB / seedling). In other treatments also, it ranged from 6.17 (VT2) to $11.72 \mathrm{ppm}$ (PT4). PSB treatments proved effective in the maximum improvement in $\mathrm{P}$ content. The performance of chemical fertilizers was not found as good, the values ranging from 3.54 (ST4) to $4.83 \mathrm{ppm}$ (MT4).

The same story was repeated in potassium $(\mathrm{K})$ content also. The values were much higher in case of biofertilizer treatments, ranging from $119.98 \mathrm{ppm}$ (VT1) to $200.41 \mathrm{ppm}$ (PT3).

Thus, it is quite evident that biofertilizers were found much superior as compare to chemical fertilizers in improving the soil fertility. Azotobactor was found the most efficient in improving the soil fertility. Azotobactor was found the most efficient in improving the organic matter and nitrogen, whereas PSB application is the best for improving phosphorus and potash.

\subsection{Effect of Chemical and Biofertilizers on Survival, Growth and Biomass of Seedlings}

(1) Survival: Survival of seedlings was found to have increased with application of biofertilizers. It was $100 \%$ in case of $\mathrm{PT}_{3}, \mathrm{AT}_{3}$ and $\mathrm{AT}_{4}$ treatments and $90 \%$ in all $\mathrm{VAM}$ treatments and $\mathrm{AT}_{2}$ treatment of Azotobactor. In other treatments, it remained unchanged (80\%) from control. In case of chemical fertilizer treatments, the results were not as good. The survival percent was minimum (55.6\%) in MT3 treatment.

(2) Root: Shoot lengths: with the application of biofertilizers, the root length varied from 21.13 (VT4) to $40.16 \mathrm{~cm}$ (PT3), whereas with application of chemical fertilizers, it varied from $20.25 \mathrm{~cm}$ (UT4) to $35.46 \mathrm{~cm}$ (ST4). The application of PSB (80 gm / seedling) was found to be the best for root development. Phosphorus is essential for root development. PSB increases the availability of phosphorus to the seedling by solubilizing phosphates in the soil and makes it available for plants. Similarly, application of single super phosphate (SSP) adds phosphorus directly to the soil.

For shoot growth, application of VAM, even in small dose of 20 gms / seedling (VT1) proved most effective. With VAM fungi, the average shoot length was $30.66 \mathrm{~cm}$ as compared to $22.20 \mathrm{~cm}$ (Control). The application chemical fertilizers, (urea, UT4) gave similar results (Av. shoot length $28.29 \mathrm{~cm}$ ), although slightly smaller than that in VT1. Thus, application of VAM is definitely the better option. If we consider the total seedling length (root + shoot), the best results was obtained with PT3 $(69.65 \mathrm{~cm})$, followed by AT3 $(66.25 \mathrm{~cm})$ and AT4 $(65.65$ $\mathrm{cm})$, whereas performance of chemical fertilizers was found far behind; the best result obtained in UT1 treatment $(58.15 \mathrm{~cm})$ followed by ST4 $(55.49 \mathrm{~cm})$.

\subsection{Collar Diameter}

The best performance in terms of collar diameter was shown by PT3 $(0.93 \mathrm{~cm})$, followed by AT3 $(0.88 \mathrm{~cm})$. Among chemical fertilizers, the best results was obtained in UT1 $(0.76$ $\mathrm{cm})$.

\subsection{Biomass}

Biomass can be treated as true indicator of growth. In terms of biomass biofertilizers proved superior to chemical fertilizers. The dry root biomass was found maximum in AT3 (19.55 gm / seedling), followed by PT4 (18.35 gm) and PT3 (18.0 gm / seedling) whereas the root biomass varied between $3.07 \mathrm{gm}$ (MT2) to $6.94 \mathrm{gm}$ (ST4) on application of chemical fertilizers. For dry shoot biomass, PT3 (12.40 gm) was the best treatment, followed by AT3 (10.95 gm) and AT2 (10.59 gm). In terms of dry shoot biomass, chemical fertilizers, in 
comparison, showed miserable performance with values varying from $1.94 \mathrm{gm}$ (MT3) to 3.75 gm (ST4). If we consider the total (below ground and above ground) dry biomass, the best performance was given by AT3 (30.5 gm) followed by PT3 (30.4 gm). On the other hand the total dry biomass varied from as low as $4.82 \mathrm{gm}$ (MT4) to 10.69(ST4) with chemical fertilizers. The results are statistically significant of $0.05 \%$ probability level (Table- 3 ANOVA)

\section{Discussion \& Conclusion}

The above account, that Azotobacter secrets growth promoting substances like Auxin, Gibberellins, Cytokinins, Indol acetic acid as well as antibiotics, which suppress and control plant pathogens (Fungi, bacteria and virus). It also helps in mineralization of plant nutrients and proliferation of useful microorganisms. The inoculation of Azotobactor stimulates nitrogen fixation, which is reflected in increase total nitrogen accumulation through nodulation. Azotobactor was found the most efficient in improving organic matter and nitrogen whereas PSB application is the best for improving phosphorus and potash.

Same results were observed for nitrogen, phosphorus and potassium also. There was significant improvement in N,P and $\mathrm{K}$ after application of biofertilizers. Thus, it is quite evident that biofertilizers are much superior to chemical fertilizers in improving the soil fertility and growth of seedling. The results are statistically significant of $0.05 \%$ probability level (Table-3 ANOVA)

\section{References}

[1] D. J. Bagyaraj and C. Machado, "Phosphorus concentration in soil solution optimum for VAM symbiosis in L. lecocephala", Annals of Forestry, vol. 4, no. 2, (1996), pp. 123-128.

[2] K. K. Chandra, S. Paroha, M. C. Sharma and K. P. Tiwari, "Dynamics of phosphorus solubilizing bacteria on growth enhancement of some forestry species", My Forest, vol. 35, no. 1, (1999), pp. 67-71.

[3] B. P. Kalawani, P Santhanakriahanan and M P Divya, "Effect of VAM and PSB in Neem", Indian Forester, vol. 126, no. 1, (2000), pp. 67-70.

[4] S Y Mashram, S A Penshwe, S N Joshi and A B Dongre, "Response of biofertilizer on biomass production of Eucalyptus camaldulensis", Annuals of Forestry, vol. 1, no. 1, (1977), pp. 43-49.

[5] H C Nagawani, H S Ananthapadmanabha, G Vajay Lakshmi and P V Samashekher, "Camparative effect of inorganic fertilizer and VAM fungi on growth of Teak plants", My Forest, vol. 34, no.1, (1998), pp. 697-700.

[6] J Raj, D J Bagyaraj and A, Majunath, "Influence of soil Inoculation with VAM and a phosphate dissolving bacterium on plant growth and $32 \mathrm{P}$ uptake", soil Biology and Biochemistry, vol. 13, (1981), 105-108.

[7] E Sieverding and S, Toro, "Influence of soil water regime on VAM > V performance of different VAM fungal species with Cassava", Journal of Agronomic Crop Science, vol. 16, (1998), pp. 322-332.

[8] A Walkey and I A Black, "An examination of the degijaref method for determination of soil organic matter and a proposed modification of the chromic acid titration method", Soil Science, vol. 34, (1934), pp. 29-38.

[9] J. L. Harley and S. E. Smith, Micorrhizal symbiosis, Academic Press, New York, (1983), pp. 483.

[10] C. L. Powell, and, D J , Bagayaraj, VA - Mycorrhiza. CRC Press. Baca Raton. FL. (1984), p 234.

[11] N. S. Subha Rao, Biofertilizer in Agriculture Oxford and IBH publication, New Delhi. Sundara Rao, W V B 1964. Bacterial fertilizers. Handbook of manures and fertilizers. ICAR, New Delhi, (1984), pp. 222-252.

[12] S. R. Olsen, et al., Estimation of available phosphorus in soil by extraction with sodium bicarbonate, U S, Deptt. Of Agri. circular, (1954), pp. 939. 


\section{Author}

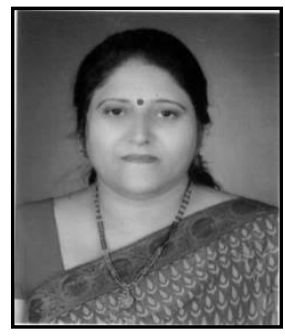

Dr. Archana Sharma is working as Head of Seed Technology Branch in M.P. State Forest Research Institute, Jabalpur -482008 (MP), India. She was awarded in Ph.D. degree in Seed Science in 1993 from Dr. H.S. Gaur University, Sagar, (Madhya Pradesh, India). She has to her credit more than 50 research paper published in both National and International journals and three bulletins and fifteen brochures. She has 22 years of research experience in seed technology. She has completed more than 20 externally funded research projects in the capacity of Principal Investigator. She has organized a number of trainings and workshops at National and State levels. She has imparted trainings to field foresters, University scholars, NGOs and Rural Communities engaged in seed technology, sustainable management and harvesting of bio resources. 